\title{
食品, 料理の栄養係数論的表現法に関する研究 (XI) Studies on Nutritional Coefficient of Food (Part XI)
}

\author{
日米国民栄養所要量の年令, 栄養素別特徵の対比について \\ (アメリカ1958年, 日本1959年現行表) \\ Comparison of Some Characteristics Concerning the Japanese \\ and American Nutritional Dietary Allowances
}

（昭 和 40 年 2 月 11 日受 理)

$\begin{array}{ccc}\text { 高 橋 紀代子 } & \text { 稲 垣 洋 子 } & \text { 蒲 原 } \rightarrow \text { 隆 } \\ \text { (Kiyoko Takahashi) } & \text { (Yôko Inagaki) } & \text { (Kazutaka Kamohara) } \\ \text { 戸 田 和 子 } & \text { 藤 原 邦 達 } & \\ \text { (Kazuko Toda) } & \text { (Kunisato Fuziwara) } & \end{array}$

\begin{abstract}
For the purpose of analysing the nutritional specificity, the tables of Japanese and American nutritional dietary allowances, the transition of nutritional balance and the increase and the rate of increase of dietary allowances per age group were figured by the introduction of the method of nutrition coefficient.
\end{abstract}

国民栄養所要量は栄美行政，指導の最も基本的な標準 値になっているが今回著者らはこれに栄養係数の手法を 適用して年令別各栄養素所要量の增加および增加率の様 相を図に示し，同じく年令別の各栄美素所要量間の平衡 関係の推移を示す四を作った。その結果これらの因によ って国民栄養所要量の年令別，栄養素別の特徴が従来の 単なる表示によるばあいよりす明瞭となり，さらにアメ リカ人の栄養所要量に関し，同様の処理によってえられ た諸関係因と対比して日米両国民の栄養所要量の質, 量 的な相連を容易に直視することができる。

\section{図および表}

\section{1. 年令別所要栄美量の栄美俰数による表現}

科学技術庁資源調査会 (1959年) の数値 ${ }^{1}$ による国民 栄養所要量を男子について20〜29才成人值を基準値 100 とする栄養係数値として表現すると第 1 表のと扰りにな る。

2. 年令別所要量の栄養素間の平衡関係の推移

第 1 表の各栄美素間の平衡関係を図示すると第 1 困か; えられる。

同様のことをアメリカ人について示すと第 2 因の通り である。たたししアメリカ人の栄嵏所要量は1958年発表の
第 1 表 日本人（男子）の栄美所要量（F.N.C.）

\begin{tabular}{c|r|r|r|r|r|r|r|r|r}
\hline 年令 & $f_{\boldsymbol{x}}$ & $f_{c a l}$ & $f_{p r o t}$ & $f_{f a t}$ & $f_{c a}$ & $f_{\boldsymbol{A}}$ & $f_{B_{1}}$ & $f_{B_{2}}$ & $f_{C}$ \\
\hline 0 & 才 & 30 & 43 & 31 & 67 & 40 & 31 & 31 & 34 \\
$1 \sim 2$ & 48 & 64 & 48 & 67 & 50 & 46 & 46 & 46 \\
$3 \sim 5$ & 62 & 71 & 62 & 67 & 60 & 54 & 54 & 62 \\
$6 \sim 8$ & 74 & 79 & 74 & 83 & 75 & 69 & 69 & 78 \\
$9 \sim 11$ & 84 & 100 & 84 & 100 & 100 & 77 & 77 & 100 \\
$12 \sim 14$ & 100 & 136 & 101 & 150 & 100 & 92 & 92 & 123 \\
$15 \sim 17$ & 110 & 136 & 110 & 133 & 125 & 100 & 100 & 138 \\
$18 \sim 19$ & 108 & 121 & 108 & 117 & 125 & 100 & 100 & 138 \\
$20 \sim 29$ & 100 & 100 & 100 & 100 & 100 & 100 & 100 & 100 \\
$30 \sim 39$ & 100 & 100 & 100 & & & & & \\
$40 \sim 49$ & 96 & 100 & 96 & & & & & \\
$50 \sim 59$ & 92 & 100 & 91 & & & & & \\
$60 \sim 69$ & 86 & 93 & 86 & & & & & \\
$70 \sim 96$ & 74 & 86 & 74 & & & & & \\
\hline
\end{tabular}

数値 ${ }^{2}$ をるちい, 日本人男子25〜29才の栄 養所要を 100 として換算し，0才については 7〜12カ月の所要昔 を用いた。（ただ蛋白質所要量は表示されていない）

3. 各栄養素所要量の年令層別增加率

第 1 図のと括り年令增加に対応する所要量の增加のし かたには各栄養素ごとにかなりの特㣲がみられる。 

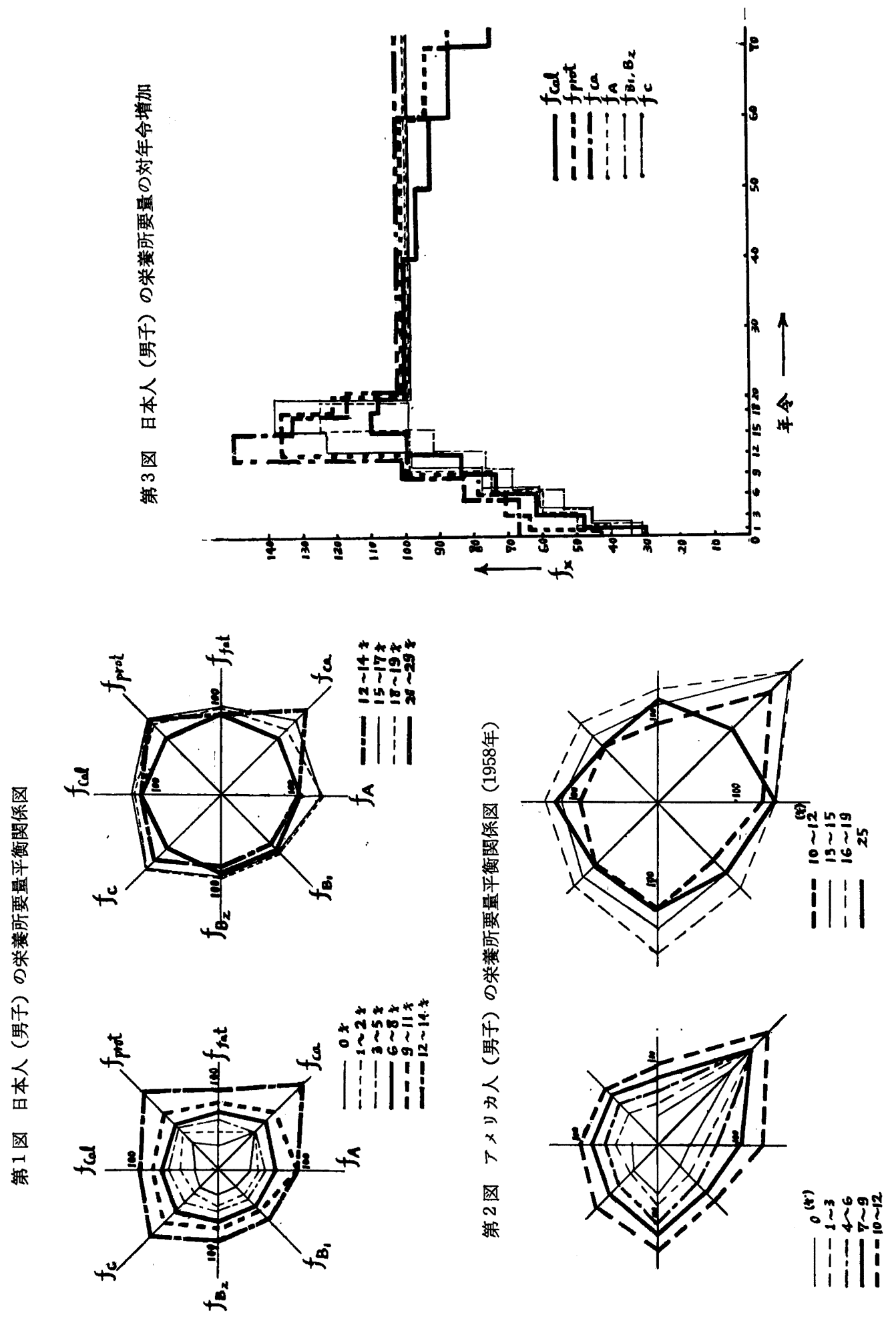

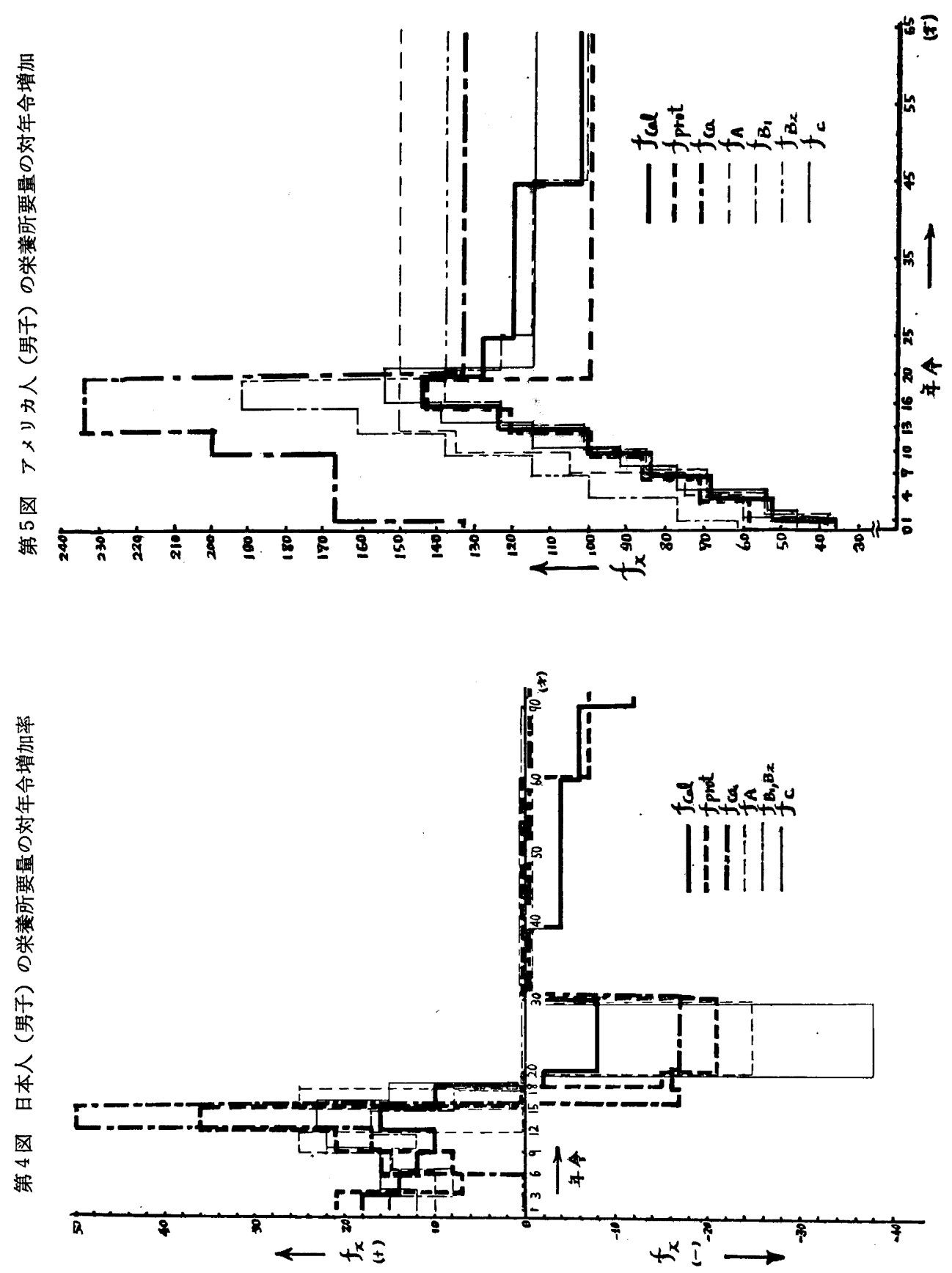

これを年令対栄盖係数値の関係図として示すと第 3 図 がえられる。ここで各年令層所要量の栄盖係数值の, 前 年令層の数値との差を図示すると第 4 四の上 うな年令層 別所要量の增減率を示す四がえられる。

たとえば20３0才の所要量は18２0才代に比べて $f_{\text {cal }}$ で $8 \%$ 減, $f_{p r o t}$ で $21 \%$ 減に相当することを示している。
4. アメリカ人の年令別所要量の増加

アメリカ人の第 2 図の数值にもとづき日本人の第 3 , 4 図に相当するすのを作ると第 $5 ， 6$ 困となる。

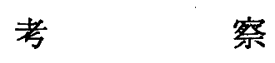

栄養係数によるときは栄美量を同じウエイトで対比す 
第 6 図 アメリカ人(男子)の栄養所要量の 対年令增加事

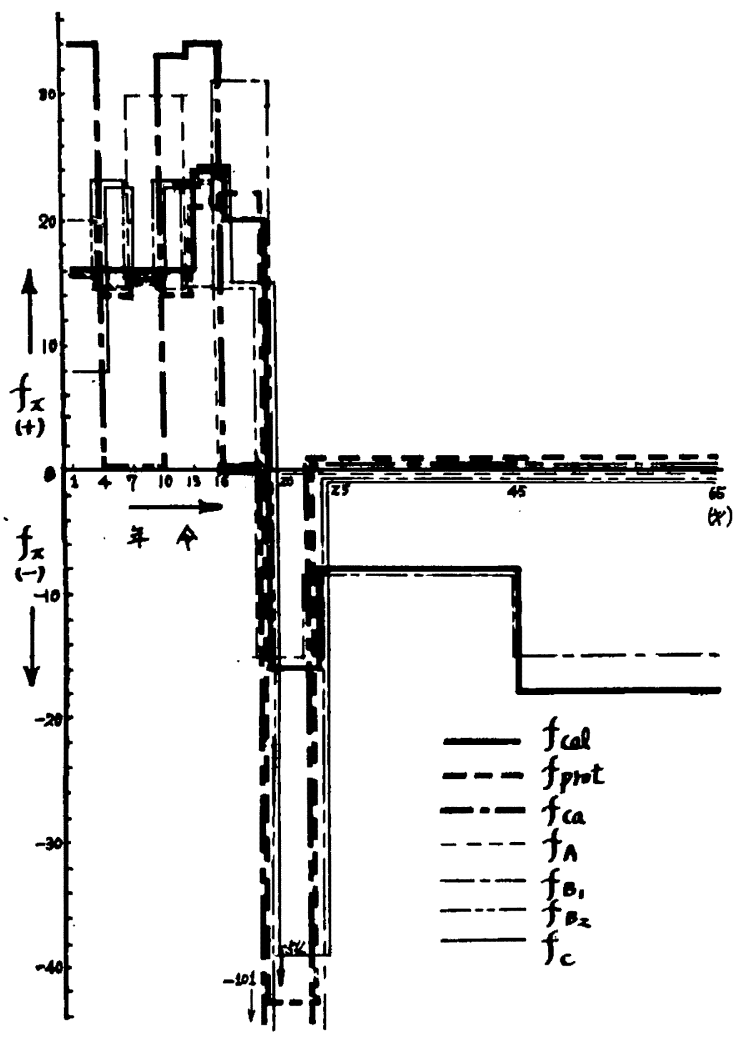

ることができる。著者らはこうした特徴を利用し，さら に係数值を四形化することによって標題のような本報の 目的を達成することをこころみた。

以下各図について考察を加える。

1. 第 1 图では日本人男子成人の基染值に対して, 各 年令層の所要量の量的比率および栄養素間平衡性の推移 をよみとることができる。たとえば，

(1) 12〜14才期の図形が特徽的であり，栄養贵供給の ハシランスについて特殊な考虑を要することを示す。

(2) これに反して成人男子の食餌とはほ同様のバラン スが許される年令層は $3 \sim 5 ， 6 〜 8$ 才代であることが わかる。この時期ではたとえば父親の食事献立の規模だ けを縮小すればよいといらことである。

2. 第 2 困ではアメリカ人の所要量間の平衡関係の日 本人のばあいとの相違がわかる。すなわち，

(1) 日本人のばあいと異なり，4〜6，7〜9才期の 栄養素間のハシランスは，必ずしも成人のそれと同様に規 定されてはいない。特にカルシウムの補給について強く 配虑されている。

（2）日本人ょり 图形の全体の形が大きく，所要量が
多いことは体位の相違によるるのであろう。

しかしこのことを考虑にいれてすなおカルッウム，ビ タミンAなどはかなり強調されており，したがって図形 あ特徽的である。

3. 第 $1 ， 2$ 四をみると所要量の年令毎の增量のテン ポが各栄養素係数值の軸ごとに異なることがわかる。第 3, 5 図ではこの関係がいっそ5明瞭に表現されている。 すなわち $1 ， 2$ の特妾をとらえると，

（1）日本人の第 3 因では $f_{x}$ の各線か滵集しているが， 逆にアメリカ人の第 5 図ではかなり蹯開していて，いず れる上昇する。これ第 $1 ， 2$ 図と同様に日米における ハシランスについての規定を異にすることに起因する。

（2）日本人の第 3 図では15才以降，図形が停滞ないし 下降する傾向がみられるが，フメリカ人の第 5 図では19 才まで上䄯をつつけけいることがかかる。このことは東 京オリンピックに猢るアメリカのハイティーン選手の 活矅，特に記緑更新の可能性と関連して興味がある。

4. 所要量增減の程度をしめす第 $4 ， 6$ 因においては アメリカ人の增减幅の激しい動きがみられるとおり，第 $1 ， 2 ， 3 ， 5$ 図の特街をいっそう明らかにしている。

以上に示したよ $5 に$ 栄養釈数の手法を導入して本報の 如く作四すると栄養所要量に関する年令，栄養素別の特 徴を明確にすることができる。るちろん,この考察の各項 目に示した事実はすで識者が着目し言及していること にすぎないかるしれない。しかしながら著者らの方法に よるとこのような結論のよみとりが具体的であり，単に 所要量表の数値について考えるよりす直接的であって, 一般への栄美教育や指導などにも効果があると考える。

結 論

栄養係数の手法を導入して，日本人とアメリカ人のば あい汇つき栄養所要量における栄養素間の平衡関係の対 年令推移を示す図，年令所要量対比図，同じく增减率を 示す四を作り，日米相互の国民栄養所要量の年令ごとの 增加のしかた，栄養素平衡性に関する特徴をとらえるこ とを試み、この上うな著者らの方法の効果について考察 を加党た。

おわりにご指導，ご缏撻ならびにご校閲をたまわった 本所副所長松山雄吉, 所長西尾雅七両博士に深く感謝申 しあげます。

\section{女献}

1) 資源調查会：日本人の栄養所要量 (1959)

2) Food and Nutrition Board, National Research Council : Recommended Dietary Allowances, (1958)

（京都市衛生研究所） 